\title{
The Contribution of Remittances: a Tacit Knowledge of Parenting Capacity in Families of Migrant Workers in East Lombok, Indonesia
}

\author{
Rika Nopitasari ${ }^{1}$, Johanna Debora Imelda ${ }^{2}$ \\ Departemen Ilmu Kesejahteraan Sosial FISIP Universitas Indonesia, Gedung Nusantara II \\ Kampus FISIP UI, Depok, Indonesia ${ }^{1,2}$ \\ \{nopitasarika@gmail.com ${ }^{1}$, johanna.deborah09@ui.ac.id $\left.{ }^{2}\right\}$
}

\begin{abstract}
Global developments make the migration of workers abroad unavoidable. Using the UNICEF child protection and welfare framework, this study provides a tacit knowledge on how remittances contribute to parenting capacity in the families of male migrant workers. A qualitative approach, with participant observation and in-depth interviews, was conducted in East Lombok District to collect the data which then was analyzed through inductive axial coding. The study showed that the remittance pattern was largely determined by the father's work. Remittances did not always contribute to the children's welfare. However, the family's stability and the fulfillment of the mother's emotional needs determined the fulfilment of the child's needs; therefore, the parenting capacity in family life increases. The interaction between family stability, maternal emotional needs, and remittances supplied by the father contribute to the fulfillment of the child's developmental needs including basic care, emotional warmth, and child guidance.
\end{abstract}

Keywords: Male Migrant Worker, Family Stability, Parenting Capacity, Remittance, Child Developmental Needs, Child Protection And Welfare

\section{Introduction}

Migration is the movement of a person or group of people from a geographical area across political and administrative borders with a desire to stay indefinitely or temporarily in a place that is not their home [1]. The migration of workers is a type of migration. A total of 2.7 million Indonesians are estimated to work abroad [2]. Indonesia has the second largest population of migrant workers in Southeast Asia, following the Philippines. In 2015 Indonesia sent 275,736 workers abroad [3]. The East Lombok Regency is home to the largest number of migrant workers in Indonesia. There were 24,526 migrant workers from East Lombok in 2014, consisting of 23,213 males and 1.313 females [4].

The search for a better income is the main reason for migration, to support the life of one's family and improve their welfare. This, however, is the source of a dilemma, asGraham and Jordan's [5] study showed that children who are left when one or both of their parents work 
abroad have a greater occurrence of disorders of psychological wellbeing such as emotional distress. Moreover, studies have shown that migration, especially if the father migrates, hurts the insecurity and loneliness of their children and wives [6]. When fathers work abroad, mothers fulfill the nurturing aspect of the father's role and care for their children; this can cause stress both physically and emotionally and can affect the care provided to the child [7]. According to a United Nations (UN) study from 2011 [8], if an emotional relationship between mother and father is well established, the father's role will be felt by the child, despite the distance with the father, but the lack of intense communication between migrant workers and their families creates problems such as divorce and polygamy [9][8], which ultimately have implications for the fulfilment of the needs of children and improving their welfare. A study conducted by Liu \& Leung [10] showed that mobile phones assist distance parenting, as they can help communicate and channel attention and affection to children. The research mentioned above shows that the migration of the father does not necessarily cause a clear division of roles, such as between the mother's domestic role and the economic role of the father as the breadwinner of the family. A father's remittance does not always guarantee an increase in parenting capacity. The father's migration may even test the stability of the roles of the other family members in cases of family instability. There have only been a few studies that show how remittances sent by fathers contributes to the improvement of parenting capacity. Therefore, this article is intended to illustrate how remittance, in a complex way, contributes to parenting capacity in the families of male migrant workers.

\section{Literature review}

\section{a. Parenting capacity}

Parenting capacity is one of the dimensions described in the Child Safeguarding and Promoting Welfare Framework developed by the UNICEF [11]. In this study the indicators selected were;(1) Basic Care, such as providing food, clothing, and personal hygiene.(2) Emotional Warmth, including taking care of the child's need for a safe, stable and loving relationship with an adult who is close to him. (3) Stability in the families, i.e., essential stability that is maintained by all family members. (4) Guidance and Boundaries that allow children to manage their own emotions and behaviors.

\section{b. Family}

There is the functional definition of the family such as emphasizing the fulfillment of psychosocial tasks and functions, including care, socialization in children, emotional and material support, and the fulfillment of certain roles [12]. The roles of the father [13] are as the breadwinner, an understanding father gives a sense of security, and as a protector or authority figure in the family, with his wisdom and loving character. According to Berns [14] types of family are the nuclear family, consisting of a father, a mother, and child(ren) and the extended family, consisting of relatives of the nuclear family who are economically and emotionally dependent on each other. Moreover, there is single-parent family, which is he parent can be either male or female and can be single as a result of the death of the partner, divorce, separation, desertion, or never having been married [15]. When the father migrates, the mother becomes a de facto single parent and bears a double burden, being responsible for taking care of the children and having to earn extra for a living [16]. When a husband works overseas, 
consistent communication with the wife is needed to fulfill the wife's emotional needs. If her emotional needs are fulfilled, she can provide good care for her children [10].

\section{c. Migrant}

An international migrant is a person who is living in a country other than his or her country of birth [17]. Labor migration is generally defined as a cross-border movement for purposes of employment in a foreign country [18]. Workers' remittances are defined by the International Monetary Fund in its Balance of Payments Manual, 6th edition as the personal cash flow of migrant workers to recipients in their origin countries [19]. Remittances are used by families to meet daily needs such as food, beverages, children's education, and to purchase investments, such as valuables, land, and homes.

\section{Method}

This descriptive qualitative study was conducted in East Lombok District, West Nusa Tenggara, Indonesia, using a review of the literature, participant observation, and in-depth interviews with 26 informants selected through a purposive sampling method. The informants were families of migrant workers whose husbands have worked abroad for more than six months and have sent remittances to the family. The key informants were biological (working and non-working) mothers who have raised their children since childhood. Mothers ( 6 people) and their children (6 people) were interviewed. The children interviewed were adolescents (age 13 to17 years old) [20]. Supporting informants were the children's mentors and counselors (4 people), neighbors or members of the extended family (6 people), and peers (4 people).

\section{Result and discussion}

\subsection{Father's Work, Remittances, and Interaction in the Family}

There were three types of male migrant worker families who participated in this study:

\section{a. Type 1}

Type 1 families were those in which the father's job was not well established, causing the remittance that is sent to be uncertain. One example of this was Family X. In this family, the father worked as a foreman at an oil palm plantation in Malaysia, and the mother was a housewife who lived with their children in Indonesia. The remittances sent by the father were quite large but were not delivered regularly, because the father's income depended on the harvest season of the oil palm. His family would receive between 10 and 20 million rupiahs after he saved his salary for some time. The remittance was sent every two to six months. During the harvest season at the oil palm plantation, he worked more and earned more. The oil palm company where the father worked only provided shelter for its workers and no food. The father would only return home and see his family once every two years. Communication was maintained by phone so that family stability was maintained. The fact that family stability was maintained indicates that the father met the emotional needs of the mother (his wife). She felt loved and cared for, even though they are far in the distance. They trusted each other and are honest with each other, and family stability was maintained. 


\section{b. Type 2}

Type 2 families were those of migrant workers whose work was quite stable but whose income was not large, such that inadequate remittance could be sent regularly. An example of this type of family was family Y. The father of this family worked as a family driver in Madina, Saudi Arabia, and the mother was a housewife in Indonesia. The remittances sent by the father were small and stable. The income was stable because he did not need to pay for his daily expenses such as food or cost of living. A remittance of 2.5 million was sent monthly to his family in Indonesia, and he came home every 2 to 3 years. Unfortunately, stable employment and income encouraged him to become polygamous, which resulted in discomfort in the family. His second wife was their neighbor.

\section{c. $\quad$ Type 3}

Type 3 families were those families in which the father's job was not stable, causing remittances to be very limited. To fulfill daily needs, the mother was forced to work, although her work was not stable either, as another informant noted. Family $\mathrm{Z}$ was one example of a type 3 family. The father worked as a palm oil worker in Malaysia and the mother worked in Indonesia to help fulfill the family's needs, such as food and pocket money for their children. Because the father's job was not stable, the remittances were small and unstable; the work depended on the harvest season and on the salary of the father that remained after it was used for daily expenses. The father usually sent between 4 to 10 million every three to six months. The mother worked as a farmer, or as a casual laborer, a stone or sand lifter worker, whenever there were opportunities to work. The father came home to see his family every 2 years. This family had good stability and formed a harmonious household. Moreover, they were committed to communicating weekly and maintaining mutual trust between partners. The father kept up communication while working abroad. When communicating, they share stories with and support each other. This attention showed the care they had for each other.

\subsection{Remittance and Parenting Capacity}

\section{a. Basic Care}

The mothers as primary caretakers at home managed the remittances from fathers to buy food and other daily needs for their families. Families with large remittances or families who received remittances every month, such as type 1 and two families, were able to provide meat. Large remittances allowed mothers to provide nutritious side dishes for their children. However, it was difficult for families with less or less-frequent remittances, such as type 3 families, to provide nutritious food for their children, such as meat or fruit. The families only consumed meat on religious holidays such as Eid al-Adha.

Furthermore, they also found it hard to provide clothing for the children. Type 1 and two families could afford to buy decent clothing for children. However, the parents of type 3 families only bought new clothes for special occasions, especially for religious celebrations such as Eid-al Fitr. In type 3 families clothing was not a top priority, because of the small amount of remittances prioritization for fulfilled basic needs.

\section{b. Emotional Warmth}

Children's emotional needs, such as love and attention from parents, demand attention in every child. In the families of migrant workers surveyed, the father, who maintains the 
stability of the family, fulfilled the emotional needs of his wife, especially in families of types 1 and 3. The father of these families established good communication with the mothers and created trust despite living in different places. Even if the father was not physically present in the family, he could still give advice and guidance to the child directly or through the mother. The opposite was seen in the type 2 family discussed above. The emotional needs of the child could not be fulfilled because of the unbearable family stability resulting from the father's polygamy. Children in this type 2 family often heard and saw their parents quarrel, causing a sense of disappointment, sadness, and discomfort. Because the father practiced polygamy, the mother's emotional needs were not fulfilled, and the mother showed her disappointment by refusing to talk with her husband over the phone. Parents who are unable to maintain family stability can cause children to feel disappointed and cause risky behaviors that may interfere with the well-being of the children

\section{c. Guidance and Boundaries}

The type 1 and type 3 families in this study had good family stability and the maternal emotional needs were met, so they were able to provide good guidance and effective limits for their children. Parents frequently discussed by phone the guidance or limits that were being applied at home, for example on the subject of worship and daily interactions. Parents of this type of family paid attention to their children and cared about their lives; this was evident from the curfew rules and hours of study and play used in the family. Because of the stability of the family, parents could guide their children to obey rules in family and society. Less guidance was given by the parents of the type 2 family. The lack of communication between the two parents made the rules and limitations unclear for the children. As a result, the children performed risky behaviors such as smoking and participating in an (illegal) motor racing. Family instability created a lack of parental concern in guiding and restricting unwanted behaviors at home, as well as in the neighborhood. It caused children to perform risky behaviors that were dangerous for them.

This analysis of the field findings has shown that the interaction between the three components, i.e., family stability, fulfillment of maternal emotions, and remittances sent by the father, significantly contributed to the fulfillment of basic child care, emotional warmth, and guidance and limitations for children. This is diagrammed below.

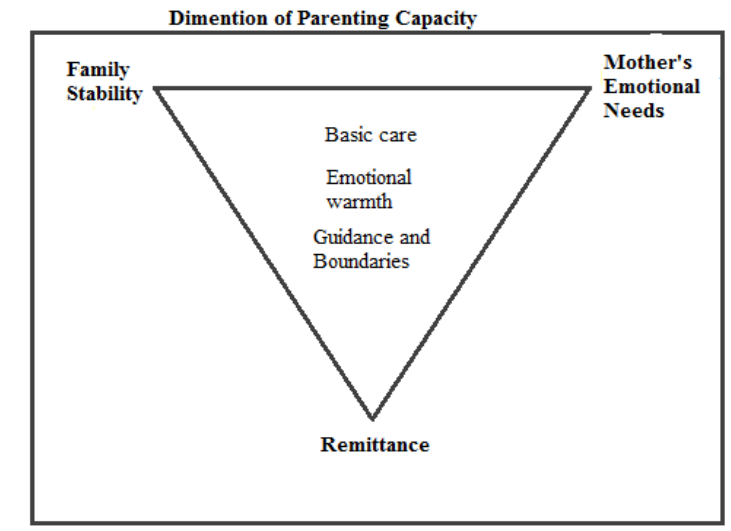

Fig. 1. Interaction between Family Stability, Mother's Emotional Needs, and Remittance. 


\section{Conclusion}

This study concluded that the parenting capacity, supported by the fulfillment of family stability, the mother's emotional needs, and remittances sent by the fathers, strongly contributes to the wellbeing of children, in terms of basic care, emotional warmth, guidance, and boundaries. The key, which must exist in the families of migrant workers, is the maintenance of family stability as the father migrates to work. When family stability is maintained, the emotional needs of the mother are fulfilled. Large and stable remittances can fulfill the needs of families, especially basic care for children. Without family stability, the fulfillment of the mother's needs, and remittances, families are unable to maintain the welfare of their children.

To create and maintain the family stability of migrant workers, it is recommended that fathers and families can take advantage of communication technologies such as Facebook and Skype, which allow families to communicate more deeply at an affordable cost. Central and local governments should create legal instruments, such as a letter of agreements, that can guarantee the fulfillment of the rights of children and families. This letter of agreement should be signed before the father decides to work abroad as a migrant worker. Furthermore, to ensure the distribution of remittances for the welfare of the children and families of migrant workers, an insurance program should be created.

\section{References}

[1] International Organization for Migration, World Migration 2008: Managing Labour Mobility in the Evolving Global Economy. Grand-Saconnex, Swiss: International Organization for Migration, 2008.

[2] International Organization for Migration, Migrasi Tenaga Kerja dari Indonesia: Gambaran Umum Migrasi Tenaga Kerja Indonesia di Beberapa Negara Tujuan di Asia dan Timur Tengah. Jakarta: International Organization for Migration, 2010.

[3] National Agency of Placement and Protection of Indonesian, Overseas Workers: Data Placement and Protection Indonesian Workers Year 2015. Jakarta: National Agency of Placement and Protection of Indonesian, 2015.

[4] Regional Development Planning Board of Nusa Tenggara Barat Province, Nusa Tenggara Barat in Data 2015. Lombok: Regional Development Planning Board of Nusa Tenggara Barat Province, 2015.

[5] E. Graham and L. P. Jordan, "Migrant Parents and the Psychological Well-Being of Left-Behind Children in Southeast Asia," J. Marriage Fam., vol. 73, no. 4, pp. $763-$ 787, Aug. 2011.

[6] S. Kousar, D. Rehman, and D. Rehman, "Male migration and problems face by the family left behind," Int. J. Innov. Educ. Res., vol. 2, no. 7, pp. 61-72, 2014.

[7] L. A. Hoang, T. Lam, B. S. A. Yeoh, and E. Graham, "Transnational migration, changing care arrangements and left-behind children's responses in South-east Asia," Child. Geogr., vol. 13, no. 3, pp. 263-277, May 2015.

[8] Department of economic and social affairs (DESA), Men in families and family policy in a changing world. New York: Department of economic and social affairs (DESA), 2011.

[9] S. Miladiyanto, "Pengaruh Profesi Tenaga Kerja Indonesia (TKI) Terhadap Tingginya Perceraian Di Kabupaten Malang," J. Moral Kemasyarakatan, vol. 1, no. 1, pp. 51-66, 
2016.

[10] P. L. Liu and L. Leung, "Migrant Parenting and Mobile Phone Use: Building Quality Relationships between Chinese Migrant Workers and their Left-behind Children," Appl. Res. Qual. Life, vol. 12, no. 4, pp. 925-946, Dec. 2017.

[11] J. Hutton, C. Clarke, and J. Smith, Framework for the Assessment of Children in Need and their Families. London: Department of Health, Home Office and Department for Education and Employment, 2000.

[12] S. Lestari, Psikologi keluarga: Penanaman nilai dan penanganan konflik dalam keluarga. Jakarta: Prenada Media Group, 2012.

[13] S. D. Gunarsa, Psikologi praktis: Anak, remaja dan keluarga. Jakarta: BPK Gunung Mulia, 1991.

[14] R. Berns, Child, family, school, community: Socialization and support. Nelson Education: Nelson Education, 2012.

[15] D. Collins, C. Jordan, and H. Coleman, Brooks/Cole Empowerment Series: An Introduction to Family Social Work. Nelson Education: Nelson Education, 2012.

[16] B. C. Diansyah, "Peran Ganda Isteri Yang Ditinggal Suami Bekerja Di Malaysia Studi Di Desa Sebangun Kecamatan Sebawi Kabupaten Sambas," Sociologique, vol. 3, no. 3, pp. 1-16, 2015.

[17] Department of economic and social affairs, International Migration Report 2015. United Nations (UN). New York: Department of economic and social affairs (DESA), 2016.

[18] Department of economic and social affairs (DESA), International Migration Policies: Government Views and Priorities. United Nations (UN). New York: Department of economic and social affairs (DESA), 2013.

[19] D. Ratha, S. Mohapatra, and A. Silwal, Migration and Remittances Factbook. Washington: World Bank, 2011.

[20] A. Mappiare, Psikologi remaja. Surabaya: Usaha Nasional, 1982. 